\title{
Volcanic Deposits and Volcanic Hazard in Santo Domingo de Heredia, Costa Rica
}

\author{
Martín Rojas-Barrantes $^{1} \&$ Mario Fernández-Arce ${ }^{2}$ \\ ${ }^{1}$ Dirección de Geología y Minas, MINAE, Costa Rica \\ ${ }^{2}$ Escuela de Geografía - PREVENTEC, Universidad de Costa Rica, Costa Rica \\ Correspondence: Martín Rojas-Barrantes, Dirección de Geología y Minas, MINAE, Curridabat 5583-1000, San \\ José, Costa Rica. Tel: 506-2234-0204, Ext. 129. E-mail: martinr@minae.go.cr
}

Received: April 6, 2016

Accepted: May 6, 2016

Online Published: June 4, 2016

doi:10.5539/jgg.v8n2p111

URL: http://dx.doi.org/10.5539/jgg.v8n2p111

The research is financed by (Sponsoring information).

\begin{abstract}
The present research aims to investigate more precisely about the geology of the Eastern region of the Santo Domingo County. Santo Domingo is part of the structural plateau in the center of Costa Rica, which is located at the foot of the Cordillera Volcánica Central (CVF) [Central Volcanic Front] and is covered by volcanic deposits. On this plateau, called Central Valley, is the highest percentage of the population of the country and therefore, a large sector of the Costa Rican population is exposed to volcanic eruptions of the volcanoes in the CVF. For existing the national system for risk management and a law that demands actions to local authorities to prevent and mitigate disaster, it is necessary to identify the threats that exist in the cantons (counties) of Costa Rica. This will serve to take the prevention and mitigation actions necessary to reduce the impact of volcanic eruptions in the area of Santo Domingo.

The research method consisted of review and analysis of previous works through literature research, data collection and analysis of boreholes from records of water-supply wells and open pits, and field work to better know the geology of the area. The results indicate that there are deposits of powerful volcanic eruptions of pyroclastic fall deposits (volcanic ash and lapilli) that mostly form clayey soils and lahars deposits that practically covers the entire territory. Underlying these deposits there is a pyroclastic flow deposit (ignimbrite), followed by lapilli tephra (a layer of pumice of at least 2 meters thick) that mark a change in the volcanic activity. Such pyroclastic flow is overlaid by an igneous presumably sub-volcanic activity of andesites interlayered with ancient tuffs, with a considerable thickness of over 350 meters according with borehole data and the exposure recognition on Pará river study sites. According to site locations (P1 to P23) of volcaniclastic deposits, there is evidence of an important environmental impact caused by the last eruptions of the CVF volcanoes. The real and current volcanic threat to the population of the County is the fall-out of ash emitted from the Turrialba and Irazú volcanoes. From local observations along the Virilla and Pará rivers sections, there is no evidence of younger pyroclastic flows overlying the volcanic sequence.
\end{abstract}

Keywords: Costa Rica, County, lava flow, Pará River, volcaniclastic, pyroclastic flow, tuff, volcanic threat

\section{Introduction}

The Central volcanic front (CVF) of Costa Rica is part of the Central American volcanic front (CAVF) that extends from Mexico-Guatemala to central Costa Rica aligned parallel to the Middle American Trench, where Cocos and Caribbean plates interact originating an active volcanism. The CVF of Costa Rica is defined as the Northern domain geochemically distinctive with Galapagos-OIB signature, compare with the rest of the Central American volcanism (Gazel et al., 2009). The CVF of Costa Rica is constituted of massive composite shield volcanoes, Platanar, Poás, Barba, Irazú, and Turrialba, the largest in both area and volume of the CAVF. The CVF borders the low- relief of Central Valley, the most populated area of Costa Rica (Marshall, 2007). This low-relief is deeply incised by river canyons, cutting the underlying Quaternary volcanic sequence. The CVF volcanoes constitutes the greatest in terms of area and volume to any volcanoes in Central America, being Barva the largest that looks like expansive rise (van Wyk de Vries, Grosse \& Alvarado, 2007). In this scenario, an 
important problem related to a complex geological active settling for geo-hazards arises, particularly volcanic hazard associated to active volcanism.

There is an agreement that dormant volcanoes are often the most dangerous ones. The mayor problem in volcanic hazard regarding reduction of volcanic risk is that most dangerous volcanoes and calderas are located in countries or regions densely populated without economic and scientific resources and political decision to adequately study and monitor them (Alvarado et al., 2007). It is essential for volcanic hazard maps detailed stratigraphic studies and distribution of deposits as well as historic and prehistoric records of eruptions to adequately determine patterns of activity, affected areas and the repose periods of a volcano. In this sense, accessibility and good exposure of outcrops is essential and conditional for this purpose (Alvarado et al., 2007). Hazard assessment in general has been improved according to intuitive criterion for those historically most active volcanoes, but should endure on those that have no historical activity like Barva, Orosí and Tenorio volcanoes in Costa Rica. This work provide new information for this important problem as a preliminary step research and look for more exposing sites where essential and useful information can be obtained.

In this paper, we analyze the most important outcrops for a specific area of the territory of the canton (County) Santo Domingo de Heredia, corresponding to the Pará River. We also include open pit and boreholes data for geologic correlation (Figure 1). It contains precise descriptions and stratigraphic columns for further analysis of volcanic hazard in the area. The current research focuses on the Eastern part of the County (Pará River) as part of a project to map the entire territory. In this context, this is an initial research advance for further work in the Virilla, Tibás and Bermudez rivers and surrounding areas to obtain the geological and hazard maps of the County. The current obtained data, is useful not only for a more precise recognition of volcaniclastic deposits regarding of the characteristics and spreading capacity, that poses a major threat in volcanic hazards but to correlate with other sites in the County for better understand of the thicknesses and extension of them. The study reveals that there are important outcrops along the Pará River not yet recognize in the literature, and constitute a valuable information as a starting point to integrate in further research of the interpretation of volcanic hazard not yet complete for the area. The importance to determine unknown sites or areas from outcrops not yet explored, in areas of quite difficult access is relevant for the purpose according with the objectives of the present work.

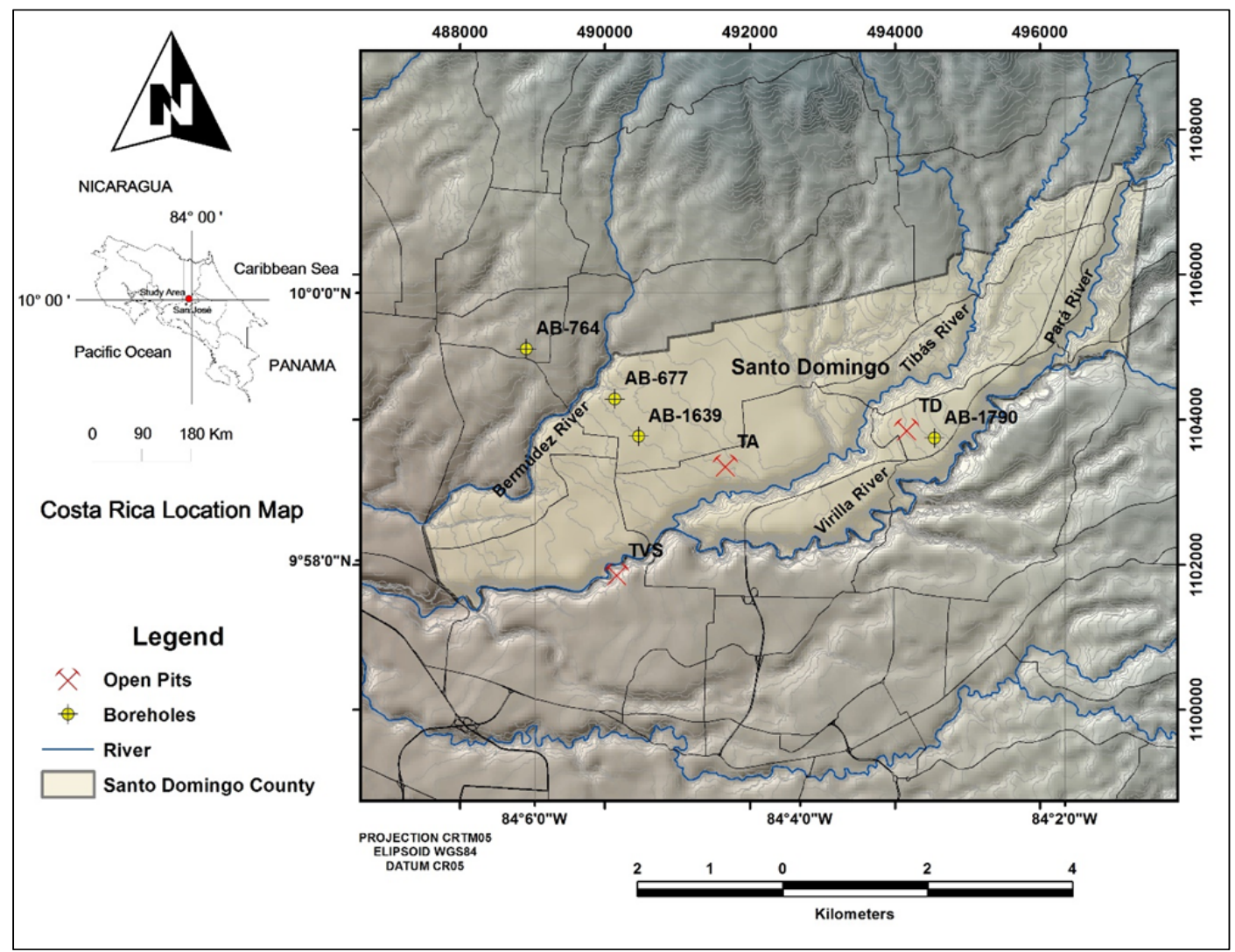

Figure 1. Location map of the territory of Santo Domingo. The area of the County is in pale yellow color. Well sites are represented as yellow circles and open pit mines are shown in red color 
Although it is known that the structural plateau of Central Costa Rica is a deposit of volcanic materials, no detailed description of the local (Santo Domingo) volcanic products has been published yet. Such a task is of utmost importance to understand the threat, vulnerability, and volcanic risk for the inhabitants of Santo Domingo. Pérez, Alvarado \& Gans (2006) pointed out that it is important to recognize events of great magnitude, like the Tiribí Tuff eruption that occurred 322000 years ago in the geological record of the Barva volcano, which still poses a very serious threat for the 2.4 million inhabitants living at its foot and southern slope. Soto \& Paniagua (1992) concluded that the southern flank of the Central Volcanic Range (Costa Rica), from San Ramon to Turrialba, is an area susceptible to suffer considerable damage from plinian eruptions, pyroclastic flows and mud flows originated in the Barva and Turrialba volcanoes. Prosser \& Carr (1987) stated that information about the geological history of the volcanoes is essential to estimate the nature of the eruptions and are useful for the assessment of volcanic threat.

This work was carried out to better understand the volcanic threat for Santo Domingo and improve local disaster risk management. Through the knowledge of the threat, local committees in charge of risk management may have better arguments and criteria for organizing the communities around the subject. There is no doubt that such committees work more effectively if they know and are aware of their environment and threats. The risk management requires that the entire population know the threats to which they are exposed and become aware of the risk that they represent.

\section{Method}

The research included bibliographic review and field work to recognize volcanic outcrops in order to better understand the geological history of the territory and describe the type of volcanic deposits precisely. This work had three stages: literature review, collection of data from water-supply wells and open pit mines used in the past for extraction and exploitation of aggregates, and field work to identify types of volcanic deposits in the lower basin of the Pará River and its Eastern confluence with the Virilla River. At the onset, we review information from scientific articles, books, and geological reports existing in three public institutions [University of Costa Rica, National Service of Underground Water and Irrigation (SENARA) and the Direction of Geology and Mines (MINAE)]. The review of previous works consisted mainly in the analysis of different definitions and descriptions of rock units and how to correlate this information with the new data obtained. Then, the new data was integrated to make a new assessment of the volcanic stratigraphy as a preliminary stage for further analysis. Stratigraphic data from wells were identified and located in the National Service of Underground Water and Irrigation (SENARA) and in the Santo Domingo Municipality. In the same way, borehole data were validated and analyze according of location, type of deposits and thicknesses in order to correlate with the fieldwork and open pit data. Boreholes and surface deposits allow us to have underground control of the geology to make more precise correlation (Colima and Tiribí Formations). Open pit mines exploited in the past for aggregates were consulted through the mining records in the Direction of Geology and Mines of Costa Rica. The importance of this exposing rocks outcrops is the general overview from a slope cutting that allow to make clear identifications of the geology to construct a stratigraphic column of a small area. This new data is integrated with the fieldwork and borehole data to stablish a common correlation framework. Fieldwork studies consisted of visiting and studying different outcrops points along the Pará River of the study area to map surface deposits. Stratigraphic columns allowe were used to know more accurately the distribution and thickness of the volcanic deposits in the County. The new data analysis consisted in recognize types of volcaniclastic deposits associated to explosive volcanism. The recognition was useful to verify the type of eruption and the uppermost stratigraphy, and to validate the threat from recent eruptions from the CVF. Residents of Santo Domingo joined the investigation both in the provision of data and fieldwork studies.

\section{Results}

\subsection{Geology of the Central Valley of Costa Rica}

The geology of the Central Plateau of Costa Rica was studied by Williams (1952) who proposed three main units: (1) lava flows deposited on the early Tertiary topography when the volcanic activity began in the Cordillera Central which he named Lavas Intracañon; (2) Nue'e ardente deposits consisting of tuffs and ignimbrites and, (3) recent lava flows, later defined as Post-Avalanche Lavas (Fernández, 1989). Such units were later classified as formations and were named Colima, Tiribí and Barva (SENARA-BGS, 1985). This volcanic activity has been explained as effusive fissure eruptions (Protti, 1986; Kussmaul, 1988 in Alvarado \& Gans, 2012), although some of them could be explained as volcanism from the medium to distal part of the Paleo-Volcanic Chain (Alvarado \& Gans, 2012) and the Barva volcano whose activity began after the volcanic activity that generated the Aguacate Group. 
The Colima Formation was defined by Fernández (1968) and studied by Echandi (1981). The latter divided it into three members: (1) Belén. This lower member contains the first lava layers deposited on Tertiary sediments and possibly on the Aguacate Complex in some sectors. The member appears in the river bed of the Virilla River and is well distributed along the Central Valley. Its composition are andesitic lavas with pyroxenes, with some transitions between andesites and basalts, interrupted by mantles of ash. It is estimated that this member has a thickness of up to 30 meters in the Virilla River canyon, (2) Puente de Mulas. It was formed after an interruption in the volcanic activity. This part of the formation consists of tuffaceous pyroclastic flow deposits both at the base and in its upper part as well as characteristic ignimbrites in the central part. Based on drilling data, its estimated thickness is up to 50 meters. The ignimbrites are dark gray or brown color and have abundant lapilli fragments in a welded matrix and a somewhat developed columnar joint structure, (3) Linda Vista. The composition of this member are andesitic and latiandesitic breccias with augite and glass (Echandi, 1981), with a dense central core. Borehole data reports a thickness of 270 meters for Linda Vista and at least seven andesitic lava flows and pyroclastic flows. They are associated to fissure emissions along fractures oriented NE - SW (Valverde, 2003).

The Tiribí Formation emerges in the North and Northwest of the Central Valley and consists of deposits of basal pumice up to 3 meters thick, followed by deposits of ash, lapilli and blocks with local intercalations of ignimbrites and andesitic lava flows. The formation has an average thickness of 45 meters, covers an area of 500 $\mathrm{km}^{2}$ and is characterized by a flat surface and is quite tabular in form. Its deposits overlying the formations Colima, Pacacua, Peña Negra, Grifo Alto and La Cruz, and are overlain by alluvions, lahars and ash of the Barva Formation (Valverde, 2003). According to Echandi (1981), this formation is divided into the following members: La Caja, Nuestro Amo and Electriona. La Caja is formed of little welded tuffs, Nuestro Amo consists of nue'e ardent deposits and the components of Electriona are well-welded ignimbrites. The Tiribí Formation is younger than the Colima Formation, its age is Pleistocene according to Denyer \& Arias (1991).

The Barva Formation materials are recent volcanic products of the Barva volcano. Four lava flows are recognized in it: San Rafael, San Antonio, Ciruelas and Cebadilla. Lithologically, the composition of these flows is andesitic-basaltic lavas rich in olivine, with thicknesses from 10 to 80 meters and intercalations of ash and occasional lapilli (Valverde, 2003).

\subsection{Volcanic Deposits in Santo Domingo}

Santo Domingo is located in the central part of the Central Valley of Costa Rica and therefore its soils are of volcanic origin. Below are details of the deposits of volcanic materials in open pit mines, wells and in an array of outcrops located along the Pará, Agrá, and Tibás Rivers (Table 1 and Figure 5).

Table 1. Boreholes and open pit data for the study area of Santo Domingo

\begin{tabular}{cccccccc}
\hline Open Pit / Borehole & ID & Northern $(\mathrm{m})$ & $\begin{array}{c}\text { Eastern } \\
(\mathrm{m})\end{array}$ & Elevation $(\mathrm{m}$. . & Thickness $(\mathrm{m})$ & \multicolumn{2}{c}{ Depth $(\mathrm{m})$} \\
\cline { 3 - 7 } & & & & & Maximum & Elevation \\
\hline Vargas Solera & TVS & 1101890.9 & 490163.1 & 1101.9 & 70.0 & ---- & 1050.0 \\
Arizona & TA & 1103369.2 & 491664.5 & 1181.5 & 70.0 & ---- & 1180.0 \\
Dent & TD & 1103866.5 & 494164.7 & 1251.2 & 62.0 & ---- & 1250.0 \\
AB-1639 & AB-1639 & 1103770.4 & 490465.1 & 1170.6 & ---- & 50.0 & 1120.6 \\
AB-677 & AB-677 & 1104280.7 & 490135.6 & 1170.0 & ---- & 175.7 & 994.3 \\
AB-764 & AB-764 & 1104971.9 & 488916.5 & 1176.7 & ---- & 146.3 & 1030.4 \\
$A B-1790$ & $A B-1790$ & 1103746.2 & 494544.6 & 1261.7 & ---- & 200.0 & 1061.7 \\
\hline
\end{tabular}

\subsubsection{Geology of the Vargas Solera Open Pit (TVS)}

The Vargas Solera open pit is located in the Santa Rosa district of Santo Domingo, on the right bank of the Virilla River, within the CRTM05 coordinates 1101870.9 North and 490163.1 East (Table 1). Locally, there are volcanic deposits of the Colima and Tiribí Formations, with a minimum and maximum thickness of 40 to 55 meters (Calvo, 1998).

The basal unit is comprised of massive lavas of andesite composition up to 10 meters thick (Calvo, 1998; Obando, 2008) that emerge in the course of the Virilla River. According to Echandi (1981) this unit is correlated with the Belén Member of the Colima Formation. 
The intermediate unit is a package of lavas and breccias of lava that overlay the basal unit and consists of three layers: a lower horizon of brecciated lava with vesicular texture, dark gray color (fresh) to reddish brown (altered); an intermediate horizon that corresponds to a layer of dark gray aphanitic andesitic lava with flow-laminated structure and jointed (fractures with or without clay mineral fill), and an upper layer similar to the lower one. According to Echandi (1981), this unit is correlated to the Linda Vista Member of the Colima Formation.

The upper unit consists of tuffs and ignimbrites of the Tiribí Tuff. It has a basal layer of non-consolidated pumice up to 2 meters thick, overlain by dark gray ignimbrite and tuff, with a minimum thickness at the site of 15 meters. According to Echandi (1981) this unit can be correlated with the Upper Member of the Tiribí Tuff. Over this unit is a clay soil of brown color of 5 meters thick (Figure 2).

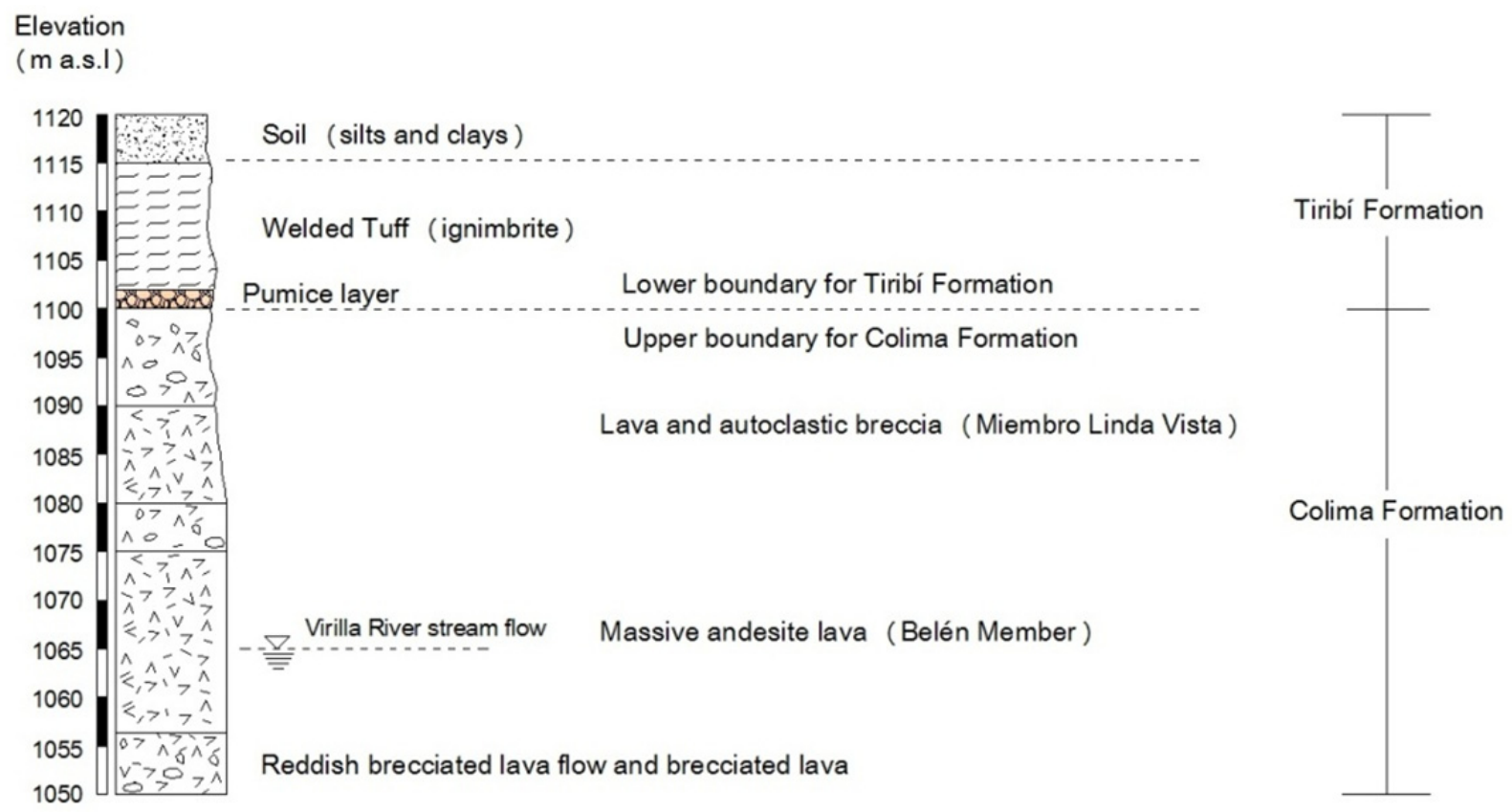

Source: Modify from Calvo, G., 1998 \& Obando, J., 2008

Figure 2. Litho-stratigraphy of the Vargas Solera open pit (TVS)

\subsubsection{Geology of the Arizona Open Pit (TA)}

The Arizona pit was a site of extraction of volcanic material for construction aggregates. It is located in Santo Tomás of Santo Domingo, within the CRTM05 coordinates 1103369.2 North and 491664.5 East (Table 1). The concession covers an area of 17.6 hectares $\left(0.176 \mathrm{~km}^{2}\right)$.

On the site, there are lavas of the Colima Formation and tuffs from the La Caja Member of the Tiribí Formation (Figure 3). Two types of pyroxene bearing andesitic lavas from Colima are recognized: (1) gray porphyritic lava, like the scoria on the outside, with few joints, (2) light gray lava with fine crystals, dense, hard and compact, with vertical joints, outer section very fractured, with well-developed flow-banded structure (Fernandez, 1989). In between the two lava flows there is a very porous brecciated lava, with evidence of calcination and with a thickness of approximately 2 meters. Petrographically, the rocks are andesitic and latiandesitic lavas with glass and augite (Echandi, 1981).

The morphology of the stratigraphic sequence is irregular, characterized by undulations of mounds and lava fronts (Obando, 1990). The total thickness of the Colima member is 30 meters (Fernandez, 1989).

The upper stratigraphic sequence consists of ignimbrites, tuffs and pumice, which expose a regular horizontal to near horizontal distribution, which is reflected in the flat upper morphology. In this sequence, there is a thickness between 2-3 meters of white pumice of rhyolitic composition, with an approximate thickness of 6 meters of ignimbrite, a section of sound, gray tuff with ash, porous matrix, slightly compact, with a thickness of three meters and weathered tuff, similar to the previous, with a thickness of about 20 meters. 
According to Marin \& Goic (1999), the Electriona Member covers the whole area of concession of the Arizona pit. Within this member, the thickness of the volcanic materials in the pit is about 70 meters.

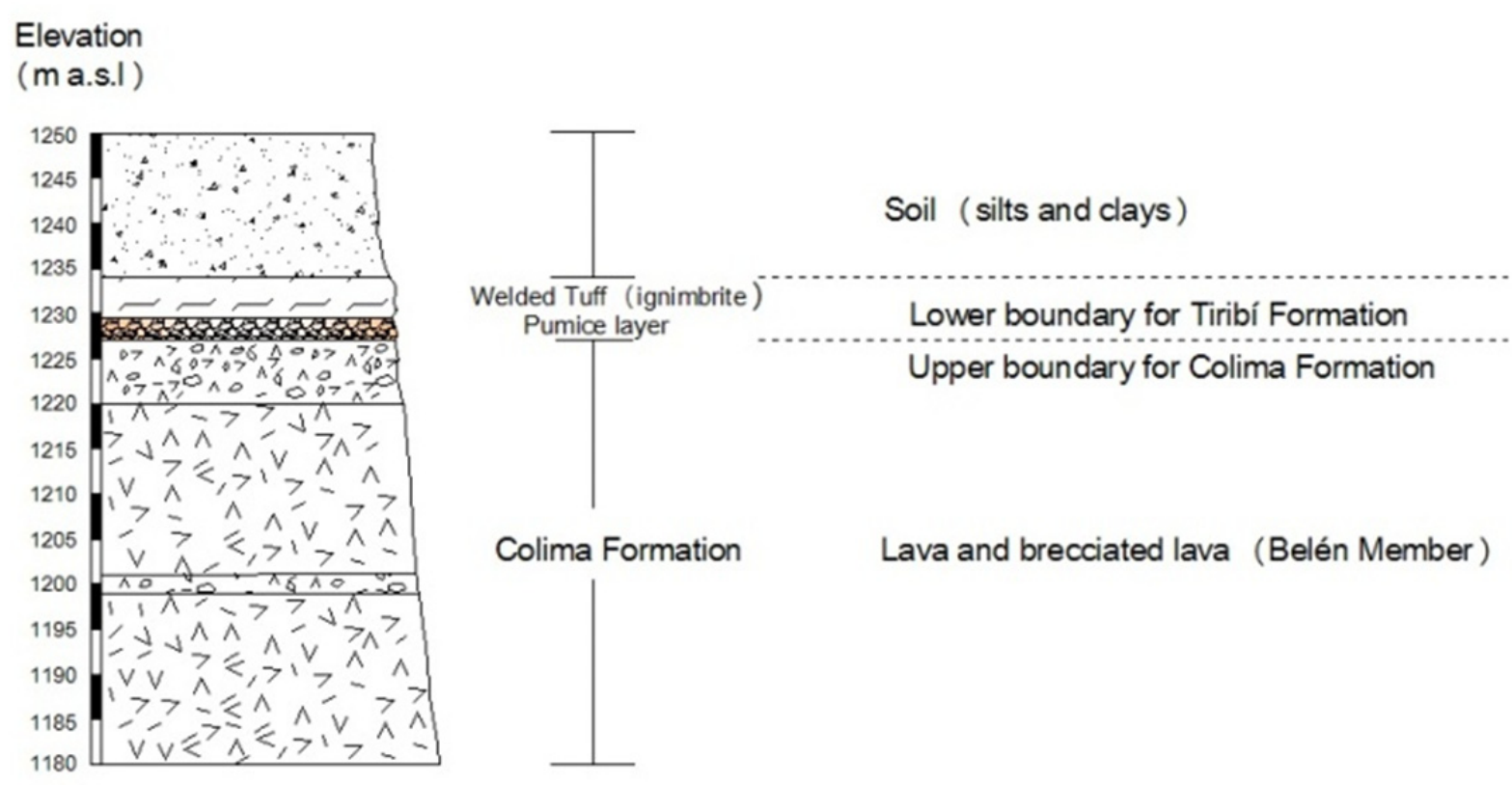

Source: Modify from Echandi, 1981; Fernández, 1989; Obando, 1990; y Marín y Goic, 1999)

Figure 3. Litho-stratigraphy of the Tajo Arizona open pit (TA)

\subsubsection{Geology of the Dent Open Pit (TD)}

The site is located in the San Miguel district, within the CRTM05 coordinates 1103866.5 North and 494164.8 East. On the topographic sheet Abra, scale 1: 50 000, from the National Geographic Institute (IGN), the site is among the coordinates $218000-219000$ North and $530000-531000$ East. On the side of the road, next to the pit some caves which were used for years to extract pumice stone are noticed (Salazar, 1993). The Dent pit corresponds to one site for extraction of pumice stone which was open in the 40's of the last century. A mining record for this pit was requested from the Direction of Geology and Mines of Costa Rica in April of 1993 to exploit the material to be used as an aggregate for construction purposes. The concession was granted and the extraction began. The exploitation lasted until March 2004, when the mining record was filed and the extraction of material ended.

According to Salazar (1993), the geology of the site corresponds with the Linda Vista Member of the Colima Formation (Figure 4). Galleries of digging show a lenticular stratum of white to cream pumice, vesicular, granular, light, and friable, with alignments of oxides and hydroxides of iron (Salazar, 1993; Valverde, 1994). The roof of the galleries is a brecciated tuff of purple withe color. On the floor of the digging galleries, there is an altered volcanic rock that can be considered as volcanic bombs (Salazar, 1993). The thickness of the gallery walls does not exceed 2.5 meters (Salazar, 1993), which is confirmed by Valverde (1994) who reported a compact lens of $2-2.5$ meters thick intercalated dark tuffaceous deposits and occasional small lenses of clays.

The exploitation and extraction method was through galleries with halls and pillars for supporting the excavation itself. The tunnels were built on the line of maximum gradient. The pillars are in the pumice layer. Some of these tunnels were excavated more than 70 years ago but are preserved in good condition (Valverde, 2003). During the exploitation, the extraction technique was manual.

A borehole close to the Dent pit shows 200 meters of volcanic deposits of lavas and autobreccias from the Lower Colima Formation, and lavas, brecciated lavas and tuffs from the Upper Colima Formation, before the deposition of the plinian pumice eruption that encloses the Dent pit in this site (Figure 4). There is no report of the pumice layer from borehole AB-1790 despite the short distance from TD pit. A correlative analysis from Dent and Vargas Solera pits and P13, suggest this layer should appear over the 1190 m.a.s. 1, and in principle should be present in borehole AB-1790. However, this could be explained by the lack of precise direct information from 
field drilling data, besides being probably be related to the lack or reduced thickness of this layer in situ, or due to the drilling process (auger action) incorporated with mud drilling of the relative low consistency and density of this volcanic deposit.

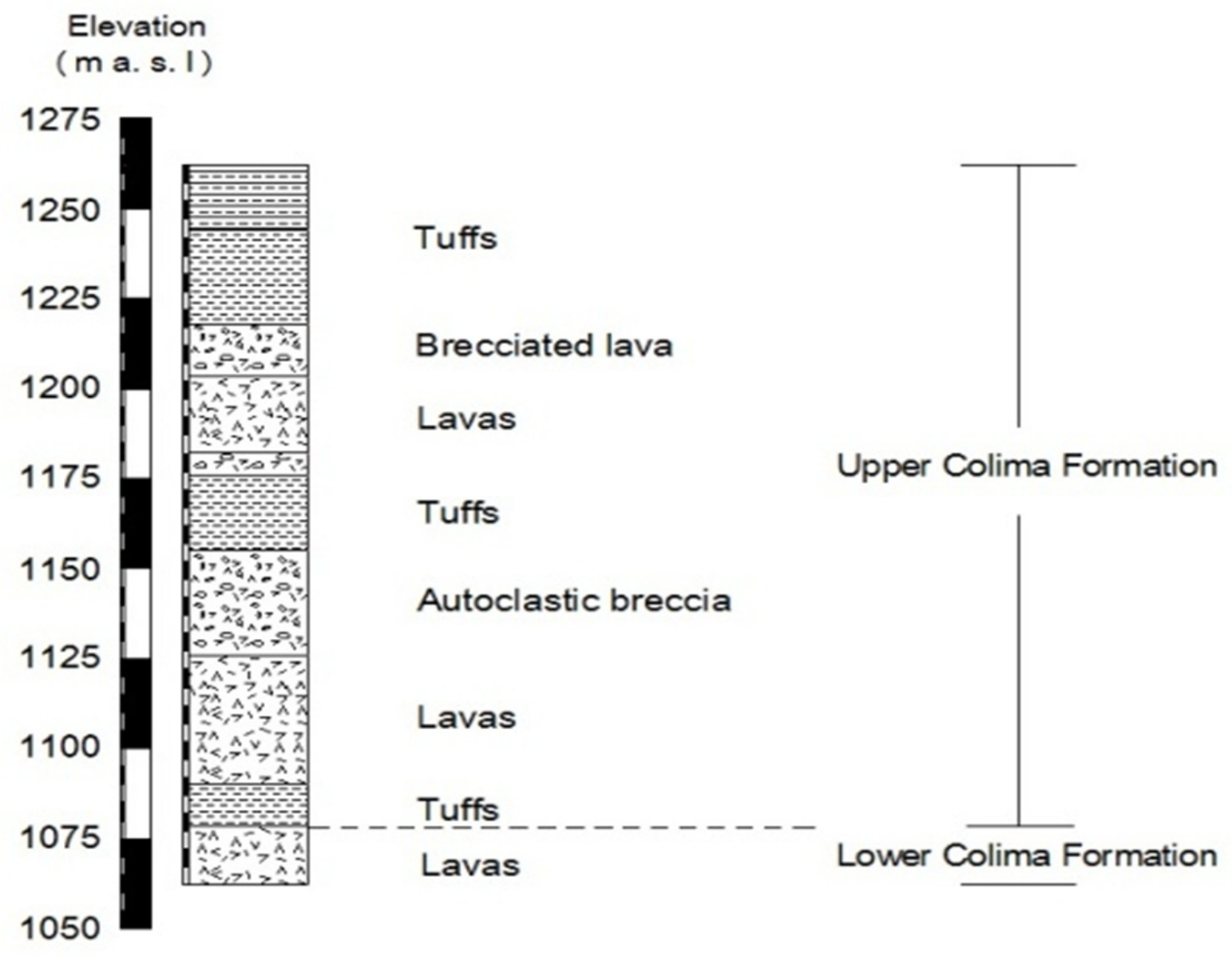

Figure 4. Litho-stratigraphy registered in borehole AB-1790

\subsubsection{Geology of the Pará River}

A series of volcanic outcrops from the upper Virilla River basin (P1 to P4), lower Pará River basin (P5 to P22) and Agrá River (P23) were subjected to analysis (Figures 5).

At (P1), downstream of the confluence of the Pará and Virilla rivers, emerges a deposit composed of angular clasts of lava in a sandy silty and quite indurated matrix. The mentioned deposit is located on the slope of the Virilla River valley and interpreted as a pyroclastic flow from Tiribí Formation. A similar deposit is found in P18 overlying the pumice layer and Colima Formation. Upstream of Virilla River (P2) and near the confluence of the Pará and Virilla rivers (P3 and P4) is an effusive volcanic deposit made of one or more blocky jointed lava flows with reddish alteration in between lava blocks or fractures (Figure 5). This material is interpreted as a lava flow front whose blocky structure is associated with mechanical fracturing of the igneous body during emplacement (autoclastic). Petrographic analysis in thin section, for one sample from P3 suggests a lava flow of andesite composition with intersertal porphyritic texture, composed of phenocrysts of felspar (plagioclase $\approx 10 \%$ ), clinopyroxene $<3-4 \%$, orthopyroxene (hypersthene $<1-2 \%$ ), and opaques $<2 \%$, in a matrix of microlithic plagioclase, interstitial glass and opaques (Figures 6A and 6B).

At P5, upstream on the Pará River, there are deposits of explosive volcanism activity, of 1.3 meters thick overlaying the volcanic deposit of $\mathrm{P} 4$, in which we recognize three different eruptive events, separated by the development of a highly oxidized to hematite soil. The base of this sequence is a lapilli tephra layer, a compact and hardened pyroclastic fall deposit of cream to yellowish color, somehow correlated with the pumice layer. Over the lapilli tephra is a very hardened paleosol of brown to yellowish color and $0.3 \mathrm{~m}$ thick. There is a layer 
of $0.2 \mathrm{~m}$ thick cream color tuff overlying the paleosol. In the uppermost part of the sequence, there is 1 meter thick, gray and very compact indurated lithic tuff which was analyzed under a microscope in order to have some information about the type of eruption activity in the geologic record specifically in this site. It, clearly shows a pyroclastic fall deposit composed of an ash matrix partially altered to clay minerals, crystals of feldspars (plagioclase), clinopyroxene (augite), lithic fragments (lavas) that are apparently not juvenile and accessory lithics altered to sericite and secondary quartz, probably from hydrothermal alteration at the volcanic conduit (Figure 6C), pumice fragments with round shaped vesicles partially altered to clay mineral (Figure 6D) and the hydrous mineral biotite is present (Figure 6E).

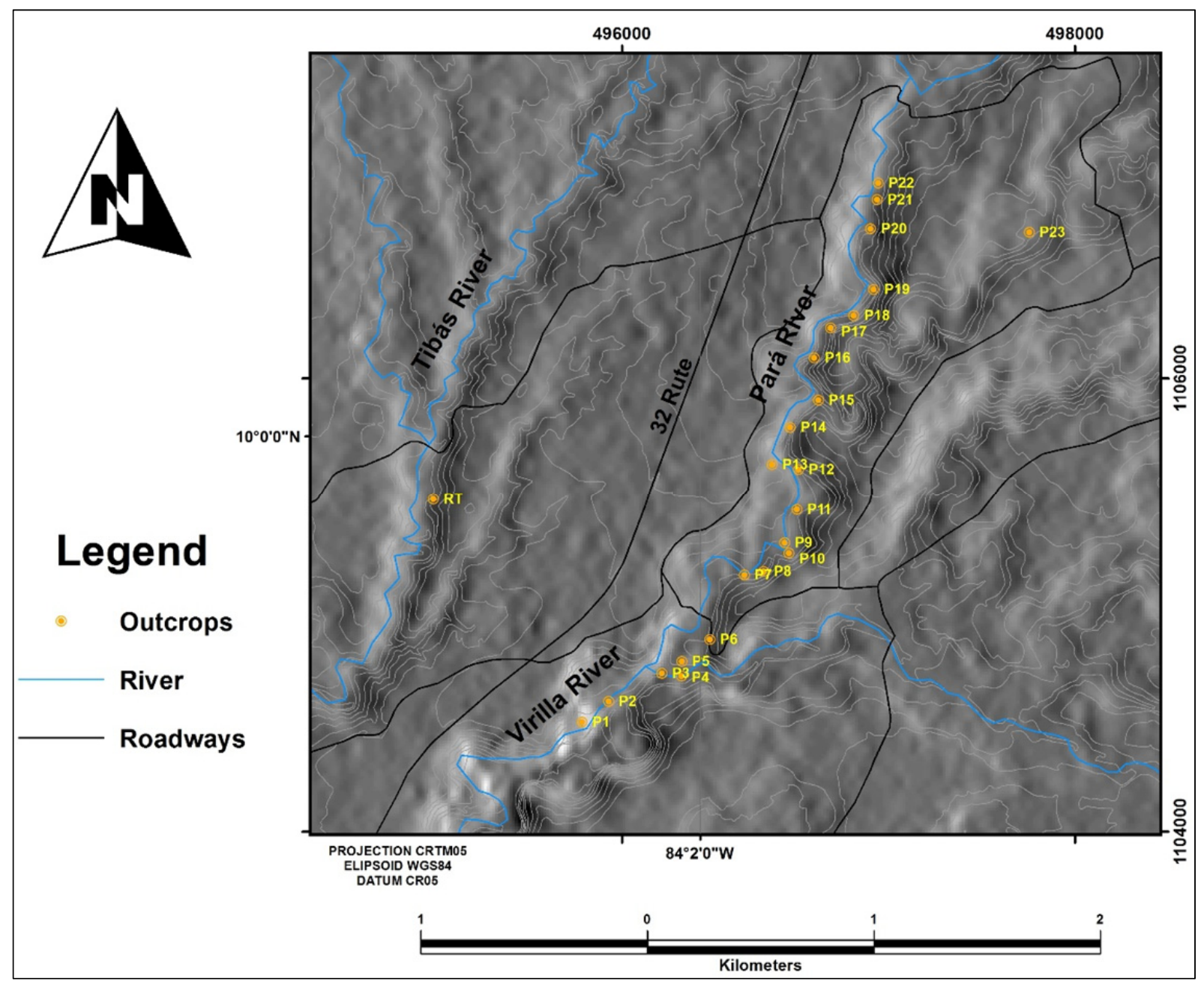

Figure 5. Location map for the outcrops subject to analysis on the Virilla River, Pará River and Agrá River 

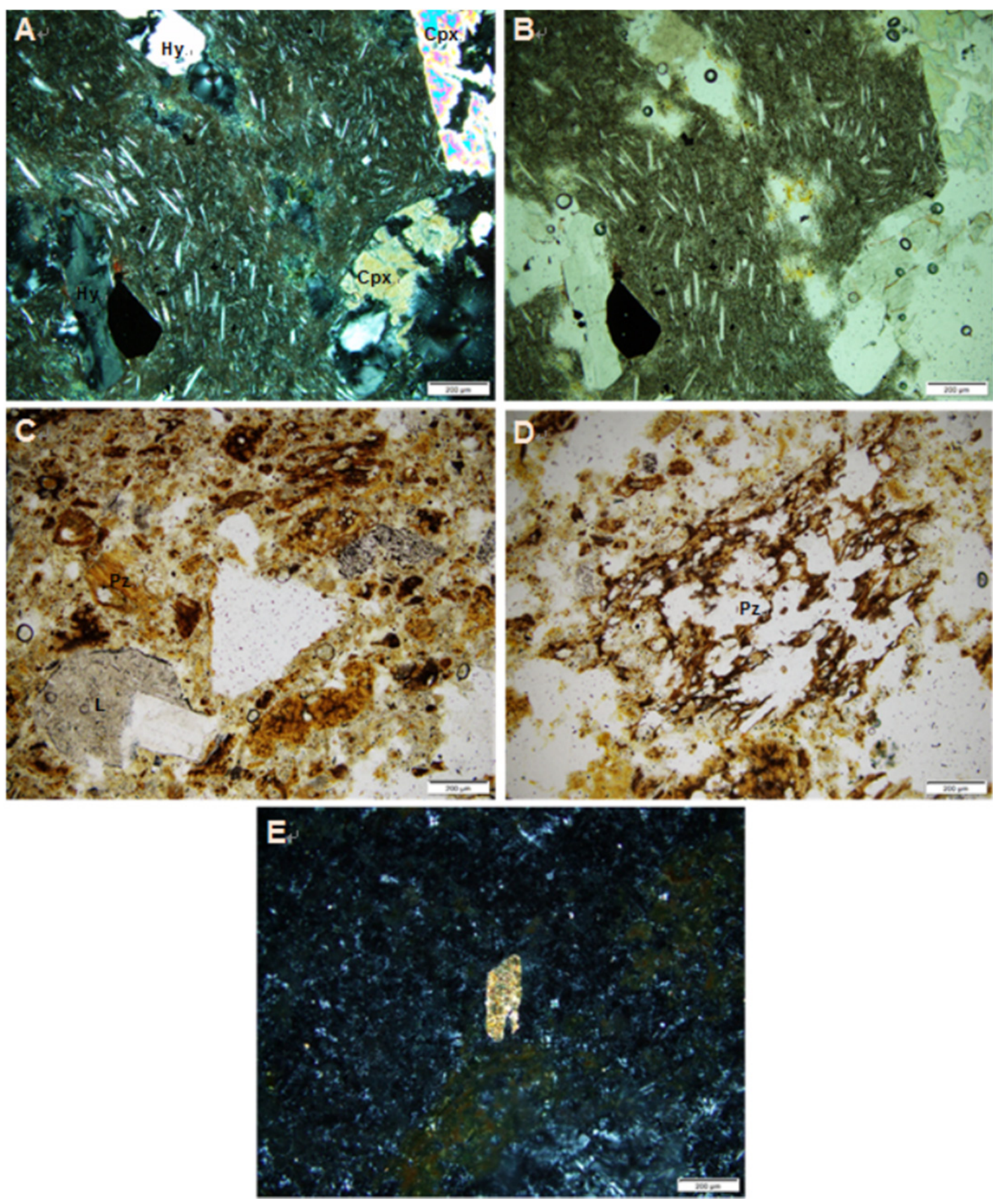

Figure 6. Photomicrographs for the samples in outcrops P3 and P5. (A) Intersertal phorpyritic texture in a groundmass enclosing plagioclase, clinopyroxene and hypersthene for sample in P3 (crossed nicols), classify as andesite for the Upper Colima Formation; (B) same as (A) in plane polarised light; (C) Pyroclastic fall deposit in plane polarised light showing details for the components of ash matrix, feldspar crystals, lithics fragments of lava and pumice fragments in sample from P5; (D) Details for pumice fragment showing no sign of devitrification and round shape vesicles in sample from P5 (plane polarized light); (E) Presence of hydrous minerals as biotite in sample from P5. Hy: hypersthene; Cpx: clinopyroxene; Pz: pumice; L: lithic fragments; Bi: biotite

Over the previous sequence (P6) there is a lahar, the youngest volcaniclastic deposit mapped in the area, and paleo-alluvions at its base which are interpreted as part of the current lahar during its deposition or as 
paleo-alluvions resulting from ancient fluvial action in the Pará River basin. The sequence from P7 to P19 along the river bank of Pará River, constitutes an exposure of lava flows varying from scoraceous black to massive gray porphyritic aphanitic textured of andesite, in a blocky-jointed to flow-laminated structure. These lava flows are associated with the Upper Colima Formation. Three remarkable characteristics are present in the sequence: (1) the considerable exposing thickness of lava flows along the Pará River canyon; (2) the presence in P13 of the plinian pumice layer overlain by a pyroclastic flow on the right stream slope of the canyon. Both lithologic units are correlated with the Tiribí Formation and similar in description to the Dent pit according to Salazar (1993). The pumice fragments are slightly altered to clay but they still evidence a fibrous silicic texture, with low content of primary minerals of magnetite and plagioclase. There is evidence of pumice stone extraction activities from the last century thorough digging galleries on this site (Figure 7); (3) a clear evidence of ancient brown-altered lithic-crystal tuffs (P18), overlain by flow-laminated andesite lava at the contact, to blocky-jointed and massive lava at top. This correlates with the description of interlayer tuffs from the Colima Formation in other places of the Central Valley according to Echandi (1981). Upstream on the river (P19), there is a blocky-jointed to massive lava flow in contact with and overlying a volcanic breccia (in appearance a debris flow). This volcaniclastic deposit consists of an advanced altered brown color matrix and clay silty composition, containing lava clasts up to $50 \mathrm{~cm}$, little altered and subangular in shape. At P19 the contact is clear between both lithologies. Upstream from P19 emerges the basal part of the previously mentioned lava flow, which looks like a brecciated deposit.

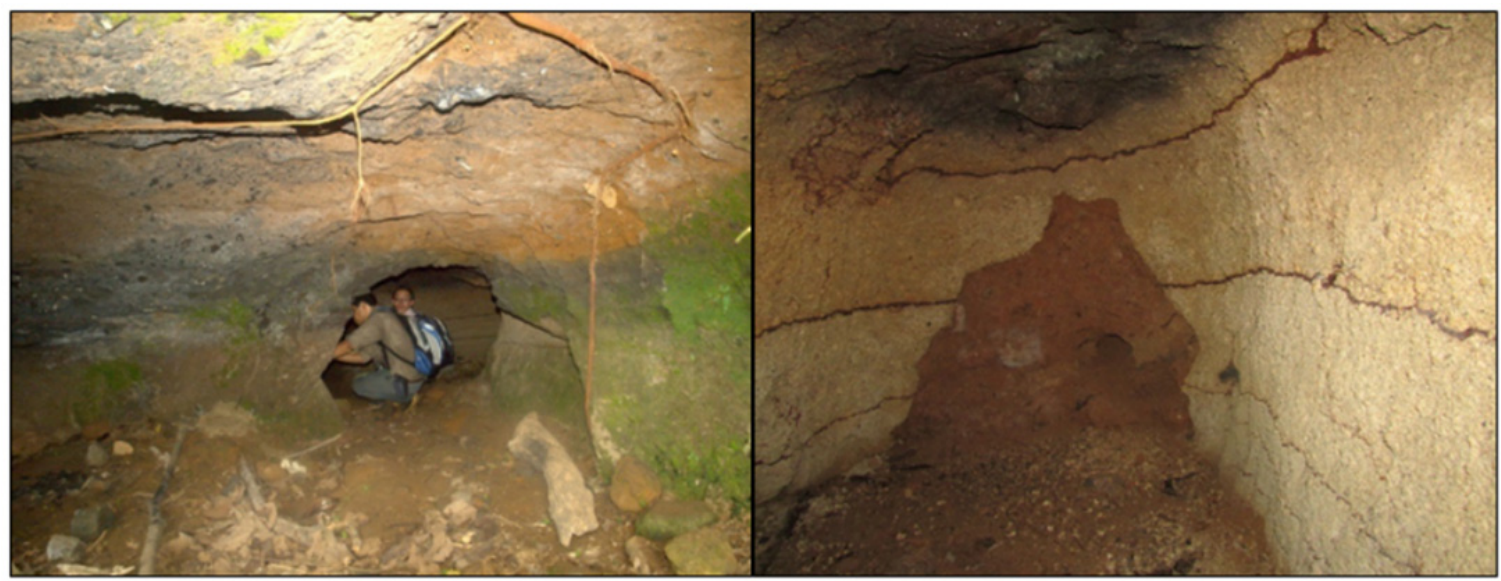

Figure 7. Digging galleries used in the last century to exploit pumice stone, at point (P13) river right of the Pará River canyon. The right picture shows the hardened compact and dense pyroclastic fall deposit of pumice

Upstream from P19, at sites P20, P21, P22 and P23 (Agrá River) secondary volcaniclastic deposits clearly emerge as debris flows/lahars, probably as different events that are differentiated by the degree of alteration of the matrix (in some cases much more hardened) and volcaniclastic components (lithics and lava clasts, scorias and pumice fragments, feldspar and pyroxene crystals) (Figure 5). These deposits include layers or lenses of hardened volcanic sands and pyroclastic material as part of the volcanic flow and deposition mechanism. In addition, alluvial lenses possibly incorporated into the flow of the lahar current were observed. In the Agrá River (P23) east from Pará River the same lahar is observed close to San Jerónimo (not shown).

From the sites subject to study (Pará River), there is no evidence of the Tiribí Tuff (ignimbrite), and that may be related to the spreading capacity and exposure which are not always continuous over the area, besides the soil and vegetation covering in the area that make continuous correlative analysis difficult. One remarkable characteristic observed from P5, is the absence of the Tiribí Tuff and instead the deposition of pyroclastic fall deposits over the Colima Formation.

\subsubsection{Geology of Wells}

By means of boreholes (AB-1639, AB-677, AB-764 and AB-1790) it is possible to know more about the geological constitution of the territory of Santo Domingo. In all drill holes, we found a geological composition of volcanic origin. For this group of borehole record, the maximum depth reached was 175.7 meters, which corresponds to an elevation of 994 meters above sea level. The first layer reported in well AB-1639 is 18 meters of a soil and red clay. Under the soil, there is a 9 meter thick brecciated lava (Figure 8). In this well, we found an 
interlayering of tuffs altered to clay and autoclastic breccia that suggests an alternation in the volcanic activity from effusions of lava and explosive volcanism.

The first layer of the well AB-677 is 26 meters thick and consists of ashes and brown weathered tuffs of and a high content of clay in the upper levels (Figure 8). At lower levels there are fragments of lava with feldspars and ferromagnesian minerals. Then, a layer of scoria and brecciated black and red lava appears. From this layer to 114 meters there is a sequence of lava flows texturally different from scoraceous, vesicular, density and crystal content from aphyric to porphyritic, color variations and autoclastic brecciated sections. At 1075 meters above sea level, there is a transition between the Upper Colima Formation and the Lower Colima Formation as interpreted by correlation with other boreholes from the area. The volcanic succession continues with a tuff, autoclastic breccia, lava flow and closes the sequence with a 6 meter thick tuff from the Lower Colima Formation that appears at 169 meters depth.

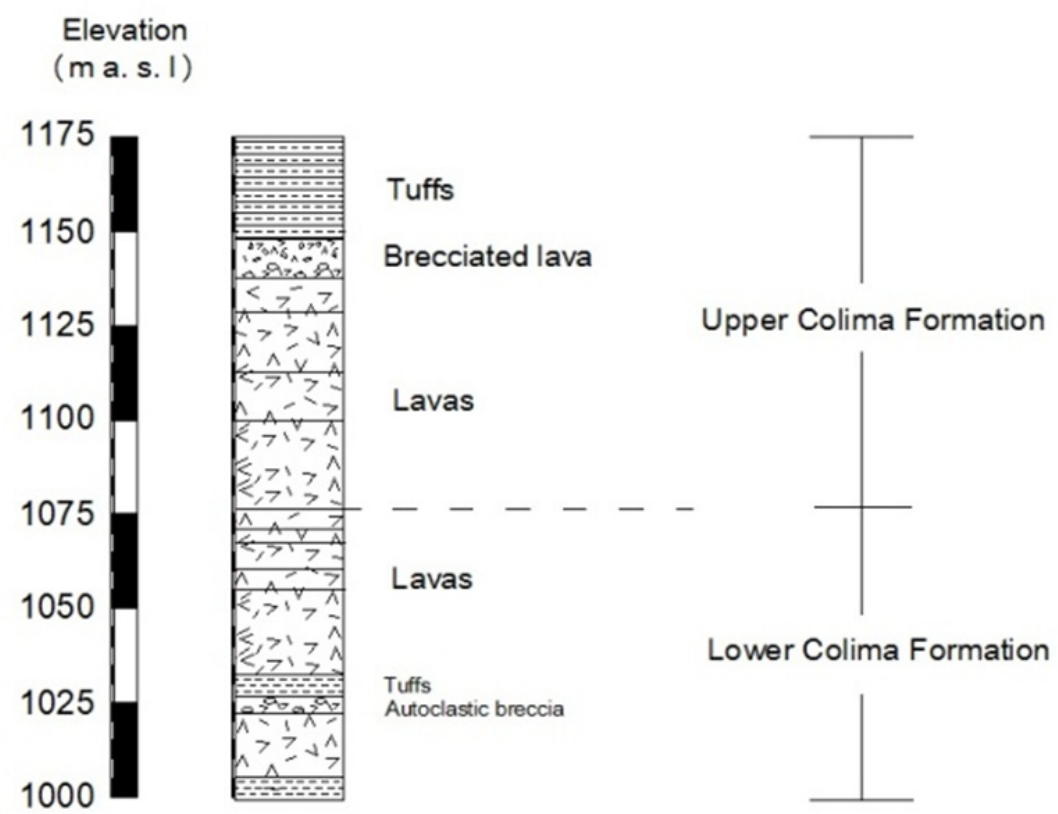

Figure 8. Litho-stratigraphy of the borehole AB-677

The upper layer of the AB-764 well is a vegetal soil and clayey ashes of 15 meters thick. From 15 to 138 meters there is a lava flow sequence occasionally alternated with brecciated lava layers. Characteristics of the sequence are similar of that from borehole AB-677. At the depth of 138.7 meters a tuff layer appears and finally a much fractured lava layer.

The borehole AB-1790 has the maximum relative depth from the group, however not that of the lowest relative elevation as referred from borehole AB-677 (Table 1). It constitutes a similar sequence of interlayering of tuffs, brecciated lava, lavas and autoclastic breccia. The uppermost layer is a tuff altered to soil on top and partially weathered tuff.

The borehole group shows a deposition of tuffs on top of the sequence, suggesting a volcanic ash cover from the latest eruptions from Barba and/or Irazú volcano in the area. Another characteristic from borehole data is the consistency of interlayering of tuffs, lavas, brecciated lavas and autoclastic breccias in the volcanic succession as seen from Pará River canyon geology and according with the descriptions from different authors in the area as explained above.

\section{Volcanic Hazard}

The International Strategy for Disaster Reduction (ISDR), 2004, defines in the context of disaster risk, hazard as a "potentially damaging physical event, natural phenomenon or human activity that may cause death or injury, property damage, disruption of social and economic activity or environmental degradation". It also indicates that threats or hazards can include latent conditions that maintain or increase the danger. Stratigraphic correlation of 
Santo Domingo County shows a boundary between the effusive volcanic deposits and deposits of explosive volcanic activity. The latter are those having the greatest implicit volcanic threat in the geological record of the area, and therefore represent a potential threat of affectation.

A new global assessment of volcanic threat has been proposed in order to assess the hazard and risk at global, regional and country scales to identify significant risk areas, gaps in knowledge and enable prioritize resources (Loughin et al., 2015). The Volcano Hazard Index (VHI) is based on the eruption frequency, registered Volcanic Explosive Index levels (VEI) and occurrence of pyroclastic density currents, lahars and lava flows. Another parameter such the Population Exposure Index (PEI) is derived and weighted from evidence on historical records or distributions of fatalities with distance from volcanoes within 10, 30 and $100 \mathrm{~km}$ (Loughin et al., 2015). In order to evaluate these parameters two measures have been proposed to evaluate the threat, understood as a combination of hazard and exposure without considering vulnerability or value, which include or combine the number of volcanoes in a country, the size of the population living within $30 \mathrm{~km}$ of active volcanoes and the mean hazard index score (VHI). The measure 1 gives the overall volcanic threat by country, and measure 2 ranks the importance of threat in each country and focuses on the proportion of the population exposed (Loughin et al., 2015). According to the distribution of volcanic threat between countries, Costa Rica ranks number 15 among the top 20 countries with the highest overall volcanic threat, and number 10 for the top 20 countries of territories ranked by proportional threat (Brown et al., 2015). However, these regional rankings are relative to the contexts and different perspectives for each country.

In Central America exist evidence of at least 26 volcanoes that have erupted during the past 10000 years and probably more than 35 that have had Holocene activity (Alvarado et al., 2007). The volcanic range of Central America from Guatemala to western Panama (with a volcanic gap of 175 - $190 \mathrm{~km}$ between Irazú-Turrialba in Costa Rica and Barú-Tisingal in Panamá), has 50 major volcanic centers with more than 400 eruptions occurred historically, and spacing of approximately $26 \mathrm{~km}$ on average, which represents one of the highest densities of active volcanic centers along any convergent plate margin (Alvarado et al., 2007).

\section{Potential Volcanic Hazard}

The most explosive, perhaps, pyroclastic event of the central Costa Rica took place 322000 years ago. Its products covered an area close to the $900 \mathrm{Km}^{2}$ and reached up to $80 \mathrm{~km}$ from its source, which was located in the caldera of the Barva volcano (Pérez et al., 2006). In 1952, the deposit was called Nue'e ardente like that of Mt Pelée, in allusion to a similar flow that killed 30000 people in Martinique by activity of the volcano Mt. Pelée, in 1902. According to Pérez et al. (2006), this eruptive event began with a Plinian eruption that caused the deposition of the layer of Tibás Pumice, with a thickness ranging from 0.5 to 3 meters. The associated pyroclastic flow reached $80 \mathrm{~km}$ westward from the source, to the community known as Orotina (not shown).

The minimum mass of magma expelled is estimated at $3.5 \times 10^{13} \mathrm{~kg}$. For this reason, the cataclysmic eruption had a magnitude of 6.6 (VEI) in the Volcanic Explosivity Index. Pérez et al. (2006) established that the Tiribí Tuff represents an Ignimbrite of great size that covered much of the region of the Central Valley of Costa Rica. The eruption began with a Plinian event that originated the layer of Tibás Pumice. According to Reyes, Fernández, Grinesky, \& Collings (2014) the territory of Santo Domingo is within the area of the flow.

The geologic record of the uppermost volcanic stratigraphy in the Central Valley, related to explosive eruptions that generate volcanic ash, tephra and pyroclastic density currents (from field work P1, P5, P13 and other authors), and according with the genetic characteristics and emplacement mechanisms of location, volumes and expansion of these pyroclastic flows in the Central Valley and Santo Domingo County, demonstrate the environmental impact that such volcanic eruptions had in the geologic history of the area. The sites subject to analysis clearly show the impact or hazard from volcanic ash and tephra fall from past eruptions of Barba volcano as primary volcaniclastic deposits (P1, P5 and P13). Lahars are present in the lower and upper upstream section of Pará River and Agrá River (P6, P20, P21, P22 and P23), evidence for the spreading capacity of volcanic mudflows in the area from past volcanic eruptions. A preliminary analysis from layer 4 of lithic tuff, a sample from P5, suggests through examination of primary hydrous minerals and pumice fragments, explosive eruptions derived from high pressures in the magmatic chamber that may be related to deeper a magmatic chamber followed by a magmatic eruption, implicit in the geologic record. If this assumption is correct, such determination may be correlated with the possibility of Barba volcano to generate similar volcanic activity in the future.

\section{The real hazard}

Soto \& Paniagua (1986) made a map of volcanic hazard for the Cordillera Volcánica Central based on data from this fall material during eruptions prior to 1986. According to them, the territory of Santo Domingo receives 
ashes only from Irazú volcano eruptive events. Nevertheless, the recent eruptions of the Turrialba volcano (Figure 9) emitted ash that fell in Santo Domingo and beyond to the west. This confirms that the entire area of the County is exposed to ash fall. Among the expected effects of the ash fall is the coverage and burial of the exposed area, including obstruction of river ways, interruption of pathways of different order and dimming of the sky, which would also affect air transport. The items most affected by the ash would be pastures, crops, and water, all of which would severely affect the economy and the well-being of the population.

The fall of ash in the territory of Santo Domingo can have effects on humans, equipment and infrastructure, agriculture, water, and domestic animals. People with chronic lung problems are particularly vulnerable to the adverse impact of volcanic ash. A common effect in humans is respiratory difficulties by fine suspended particles in the air and an increase of asthma attacks. Other effects include runny nose, sore throat, bronchitis, eye problems, and skin irritation. The volcanic ash can be poisonous to animals and cause diseases, intestinal injury and metabolic disorders. Chronic Fluorosis causes lesions in the body, and death. When fluorine is identified in the pastures, it is recommended to evacuate the livestock whose main threat is the ingestion of ash both inhalation by their respiratory system and eating vegetation covered with ashes.

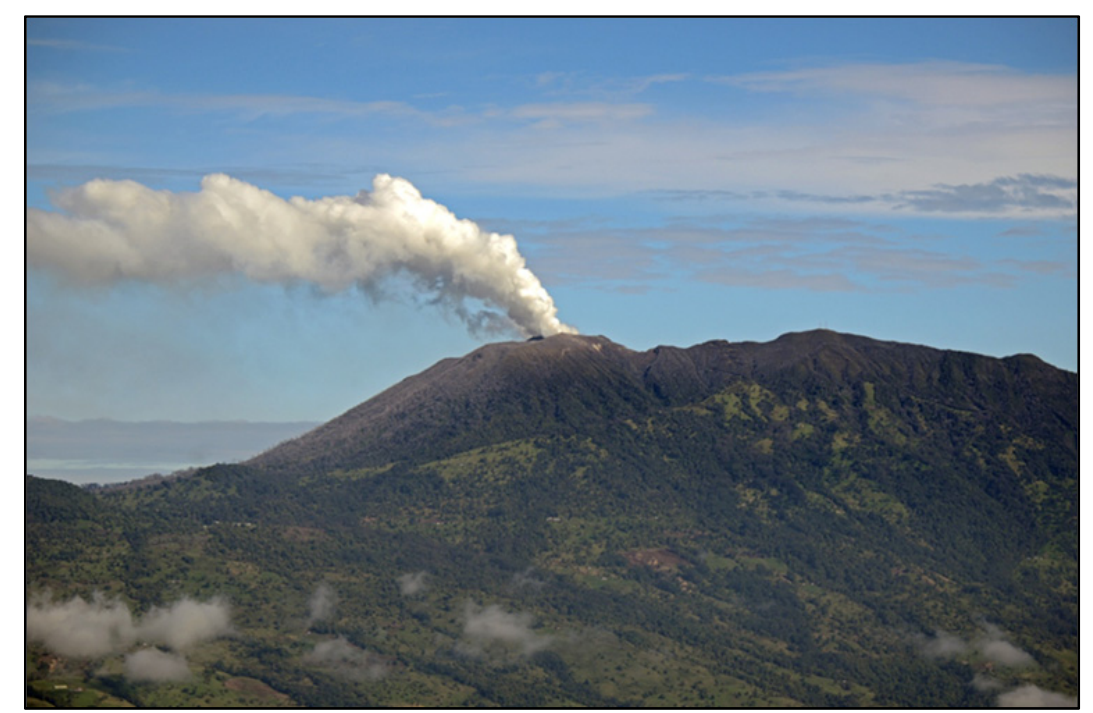

Figure 9. Exhalative activity of Turrialba volcano on November $13^{\text {th }} 2014$

The equipment and infrastructure can be seriously affected by the ash fall. Particles that would affect the operation of the cooling system could infiltrate in refrigeration systems. All computer systems could receive ash and stop working, causing power outages and data loss. The supply of drinking water could also have problems. The supply of drinking water in the County comes from wells and the extraction of water from surface springs. Therefore, the fall of large volumes of ash could pollute surface water sources and cause disruption of service by the decrease in the quality of the water and by breakdowns of pumping equipment. In addition, the weight of the ash could cause the collapse of roofs of houses of low resistance and economic condition.

Both traditional and modern agriculture, which operates with computer systems, would be severely affected by ash fall. Traditional agriculture includes basically the cultivation of coffee and some tomato plantations. In the eastern part of the County a small but modern planting of vegetables and herbs and spices (basil, celery, green onion, oregano, parsley, rosemary, thyme) whose irrigation and nutrition is carried out by means of a computer system has been identified. If the ash reaches such a system, the production would be lost completely. Finally, the weight of the ash can affect the survival of plants, increase the costs of the harvest and reduce production.

Alvarado (2008) indicated that in the very recent past our ancestors witnessed large eruptions that affected dozens and even hundreds of square kilometers and that such eruptions will occur in the future so it is likely that this century will witness these eruptions. Today, Turrialba volcano is presenting mainly phreatomagmatic activity with intermitting explosions, expulsing volcanic ash fall-out over one part of the Central Valley. This activity is affecting mainly agriculture (pastures and crops), transportation, water supply, domestic animals, electric lines, equipment and health. Economic losses are now being evaluated for people leaving around surrounding areas of the volcano. 


\section{Discussion}

The environmental impact of volcanism in the area has been prove through examination of local geology from ancient to present volcanic deposits. The volcanic hazard in the area is evaluated on the basis and recognition of recent volcanic deposits. No detailed information about the geology has been made yet, mainly in the river canyons of the Canton where most of the exposing of geology is present. The study provide new data that is in good agreement with previous works at regional scale, and report new local data useful to estimate volcanic hazard in the region, and continuing future work in the field. Imprecisions arise from the lack of continuous correlative analysis in a quite amount of outcrops and sites. Regarding the differences from previews works on geology and volcanic hazard, the present work has a much more detailed information of outcrops and petrographic analysis which strongly suggests explosive volcanic activity in the past.

Based on the compiled data of boreholes, open pit mines and field work geology, the studied area has been affected by an active volcanism since Pleistocene time. The lower contact with the Aguacate Volcanic Group from Pliocene - Miocene was not observed in the field and neither in the drilling core samples. It is clear that this volcanism was very active and dynamic as inferred from the stratigraphic correlation of interlayering of lava flows, autoclastic breccias and tuffs (plateau), pyroclastic flows deposits, pyroclastic fall deposits, debris flows and paleosols. The exposed volcanic sequence along the Pará, Virilla and Agrá rivers, is a clear evidence of this volcanic dynamic process. Different events of flow-laminated to blocky-jointed and massive lava flows interlayering with lithic-crystal tuffs and ancient debris flows in between reveals the intensity of the volcanic activity in the past. On top, there is deposition of tuffs and probably weathering products of volcanic deposits from the most recent volcanic activity. Petrographic analysis confirms explosive volcanism registered in the volcaniclastic deposits of ancient tuffs in the geologic record. The presence of orthopyroxene as a phenocryst fase in sample P3 (Figure 6A), is in good agreement with the presence of this mineral in basaltic lavas in central Costa Rica since the Late Miocene, as a product of change in the source by metasomatic addition of silicate-rich melts to the mantle source (Gazel et al., 2009).

Three main problems that made difficult the interpretation of volcanic deposits in the area are: (1) the rock alteration that mask the real interpretation of volcaniclastic deposits (pyroclastic density currents, tephra-stratigraphy); (2) the considerable thicknesses of soils that covers the well exposing of the uppermost geology and mask in the same way the real interpretation of volcanic deposits, particularly important as deduce from site P5, where a good conserved outcrop allow proper interpretation of volcanic activity; (3) vegetation that play an important role in restricting the access to some places of the area. Despite those limitations, it was possible to recognize a sequence of volcanic events that caused an important environmental impact present in the studied area. This issue should be a concern because the possibility that some kind of similar event could happen in the near or far future cannot be ruled out. In the eastern part of the County, there is evidence of deposition of volcaniclastic deposits (ancient and recent debris flows and tuffs) that can be considered as real threat due to the spreading capacity of this deposits and the development of human settlements. According to the geologic record, there was a transition in the magmatic activity from lava flows (Colima Formation) to explosive activity (Tiribí Formation). The culmination of this activity was the pyroclastic fall of ash and lapilli from the last eruptions of the CVF. The recent volcanic activity of Turrialba and Irazú volcanoes are in the actual context of this threat for the County area.

Further field work is expected to be done on the north, south, central and western part of the County in order to better understand the geology and volcanic hazard for the County. In this sense, this work is a preliminary research of the area that make a step for further investigation in this subject and obtain the geological and hazard maps for the County at the scale 1:5000.

\section{Conclusions}

This study reveals that the surface of the territory of Santo Domingo is covered by recent clayey soils from volcanic ashes and partially altered tuffs. According to the borehole data (water-supply wells), open pits, and field observations, the top layer of the geological sequence is a soil composed of clays, volcanic ash, and lahars in small areas. The clayey soil deposits have been probably derived from the ash cover. The observed soil minimum and maximum thicknesses are 5 and 26 meters. Stratigraphic location of the ashes matches the recent eruptions of the volcanoes in the Cordillera Central. The last eruptions of the Turrialba volcano ensure that ashes generated in that volcano can fall in the entire studied area. Beneath the ashes and recent lahars are the deposits of pyroclastic fall and pyroclastic flows from the Tiribí Formation. They were observed in the open pits Vargas Solera, Arizona and Dent. They also were confirmed at the point outcrops P1, P5 and P13. In both the Dent pit and P13 there is evidence of the pumice layer, exploited in the past from digging galleries, which are part of the 
Tiribí Formation. Under these pyroclastic deposits are lava flows, autoclastic breccias and tuffs of the Colima Formation.

According to the identified and registered events, the real and current volcanic threat to the population of the County is the fall of ash emitted from the volcanoes of the Cordillera Volcánica Central, in particular the Turrialba and Irazú volcanoes. At least from the local observations along the Virilla and Pará river sections, there is no evidence of younger pyroclastic flows overlying the volcanic sequence.

\section{Acknowledgments}

The authors would like to thank the citizens of the Santo Domingo County, Armando Vasquez, Oscar Sojo, Rafael Bolaños, Ileana Murillo and Gonzalo González for their support during the field work planning, historical and archeological information about the County. SENARA for the borehole information supply. The Direction of Geology and Mines of Costa Rica for its support and make available for consulting open pit mines records. Both were useful for stratigraphic correlation during the field work. We gratefully acknowledge Edward Hakanson for the English text revision of this paper.

\section{References}

Alvarado, E. G., Soto, G. J., Pullinger, C. R., Escobar, R., Bonis, S., Escobar, D., \& Navarro, M. (2007). Volcanic activity, hazards, and monitoring. In: Bundschuh, J., \& G. E. Alvarado (Eds.). Central América: Geology, Resources and Hazards (pp 1154 - 1187). Taylor \& Francis Group plc, London, UK.

Alvarado, G. E. (2008). Los Volcanes de Costa Rica: geología, historia, riqueza natural y su gente. San José: UNED.

Alvarado, G. E., \& Gans, P. B. (2012). Síntesis geocronológica del magmatismo, metamorfismo y metalogenia de Costa Rica, América Central. Revista Geológica de América Central, 46, 7-122.

Brown, S. K., Loughlin, S. C., Sparks, R. S. J., Vye-Brown, C., Barclay, J., Calder, E., Cottrell, E., Jolly, G., Komorowsky, J. C., Mandeville, C., Newhall, C., Palma, J., Potter, S., \& Valentine, G. (2015). Global volcanic hazards and risk. In S. C. Loughlin, S. Sparks, S. K. Brown, S. F. Jenkins \& C. Vye-Brown (Eds), Global volcanic hazards and risk (pp. 81 - 172). http://dx.doi.org/10.1017/CBO9781316276273

Calvo, V. G. (1998). Proyecto de explotación en cantera del Tajo Vargas Araya, Santo Domingo de Heredia. Inmobiliaria Vargas Araya S.A, estudio técnico elaborado por geodesarrollos ambientales (GEODESA). Dirección de Geología y Minas, San José, Costa Rica.

Denyer, P., \& Arias, O. (1991). Estratigrafía de la región central de Costa Rica. Revista Geológica de América Central, 12, 1-59.

Echandi, E. (1981). Unidades volcánicas de la vertiente norte de la cuenca del río Virilla. Universidad de Costa Rica, San José. Tesis Licenciatura, 123.

Fernández, C. M. (1989). Proyecto de explotación minera del Tajo y Quebrador Arizona, Santo Tomás de Santo Domingo, Heredia. Expediente Minero N 2161. Dirección de Geología y Minas, San José, Costa Rica.

Fernández, M. (1968). Las unidades hidrogeológicas y los manantiales de la vertiente norte de la cuenca del Río Virilla. Informe técnico Ministerio de Agricultura y Ganadería 27, 1 - 44, San José, Costa Rica.

Gazel, E., Carr, M., Hoernle, K., Feigenson, M., Szymanski, D., Hauff, F., \& Bogaard, P. (2009). Galapagos OIB signature in southern Central America: Mantle refertilization by arc - hot spot interation. Geochem. Geophys. Geosyst., 10(2), 1-32. Q02S11. http://dx.doi/10.1029/2008GC002246

International Strategy for Disaster Reduction (ISDR), 2004. Living with Risk. Vol. I. United Nations, New York and Geneva, $431 \mathrm{p}$.

Loughlin, S. C., Vye-Brown, C., Sparks, R. S. J., Brown, S. K., Barclay, E., Calder, J., Cottrell, E., Jolly, G., Komorowski, J. C., Mandeville, C., Newhall, C., Palma, J., Potter, S., \& Valentine, G. (2015). An introduction to global volcanic hazard. In: S.C, Loughlin, S. Sparks, S.K. Brown, S.F. Jenkins \& C. Vye-Brown (Eds). Global Volcanic Hazards and Risk (pp 1 - 40). http://dx.doi.org/10.1017/CBO9781316276273

Marin, G. F., \& Goic, C. T. (1999). Estudio geológico geofisico en la zona norte del Tajo Arizona, Santo Tomas de Santo Domingo, Heredia. Expediente minero N 2161. Dirección de Geología y Minas, San José, Costa Rica.

Marshall, J. S. (2007). Geomorphology and physiographic provinces. In: Bundschuh, J. \& G.E. Alvarado (Eds). 
Central América: Geology, Resources and Hazards (pp 131 - 178). Taylor \& Francis Group plc, London, UK.

Obando, S. J. (2008). Informe anual de labores del periodo diciembre 2007 - noviembre 2008 del Tajo Vargas Solera. Expediente minero $N^{\circ}$ 2602. Inmobiliaria Vargas Solera S.A, San José, Costa Rica.

Obando, V. J. (1990). Plazo recomendado, comprobación de campo y revisión del adendum al programa de explotación expediente minero $N^{\circ} 2161$. Dirección de Geología y Minas, San José, Costa Rica.

Pérez, W., Alvarado, G. E., \& Gans, P. B. (2006). The 322 ka Tiribí Tuff: stratigraphy, geochrology and mechanisms of deposition of the largest and most recent ignimbrite in the Valle Central, Costa Rica. Bull. Volcanol 69, 25 - 40. http://dx.doi.org/10.1007/s00445-006-0053-x

Prosser, J., \& Carr, M. (1987). Poás Volcano, Costa Rica: Geology of the summit region and spatial and temporal variations among the most recent lavas. Journal of Volcanology and Geothermal Research, 33, $131-146$. Elsevier Science Publishers B.V., Amsterdam, The Netherlands.

Reyes, J., Fernández, M., Grinesky, S., \& Collings, T. (2014). Natural Hazards in Santo Domingo de Heredia, Costa Rica, Centrral América. Natural Science. 6(3), 121-129.

Salazar, G. (1993). Cálculo de reservas y estudio técnico financiero del Tajo Dent, San Miguel Sur de Santo Domingo, Heredia. Expediente minero No 2322. Dirección de Geología y Minas, San José, Costa Rica.

Servicio Nacional de Aguas Subterráneas, Riego y Avenamiento [SENARA-BGS] (1985). Mapa hidrogeológico del valle central de Costa Rica. Escala 1: 50 000. British Geological Survey - SENARA, San José, Costa Rica.

Soto, G., \& Paniagua, S. (1992). La Cordillera Volcánica Central (Costa Rica): sus Peligros y Prevenciones. Revista Geográfica de América Central, 25(26), 291 - 304.

Valverde, M. (1994). Informe anual de labores del Tajo Dent periodo 1993 - 1994, San Miguel Sur de Santo Domingo de Heredia. Expediente minero N ${ }^{\circ} 2322$. Dirección de Geología y Minas, San José, Costa Rica.

Valverde, M. (2003). Informe anual de labores del Tajo Dent periodo 2002 - 2004, San Miguel Sur de Santo Domingo de Heredia. Expediente minero N ${ }^{\circ}$ 2322. Dirección de Geología y Minas, San José, Costa Rica.

Van Wyk de Vries, B., Grosse, P. \& Alvarado, G.E. (2007). Volcanism and volcanic landforms. In: Bundschuh, J. \& G. E. Alvarado (Eds). Central América: Geology, Resources and Hazards (pp 179 - 210). Taylor \& Francis Group plc, London, UK.

Williams, H. (1952). Volcanic History of the Meseta Central Occidental de Costa Rica. Univ. California. Public. Geol. Sci., 29(4), 145 - 180. Berkeley and Los Angeles.

\section{Copyrights}

Copyright for this article is retained by the author(s), with first publication rights granted to the journal.

This is an open-access article distributed under the terms and conditions of the Creative Commons Attribution license (http://creativecommons.org/licenses/by/3.0/). 